\title{
HLA Class II Restricted T-Cell Reactivity to a Developmentally Regulated Antigen Shared by Leukemic Cells and $\mathrm{CDB3}^{+}$Early Progenitor Cells
}

\author{
By Tuna Mutıs, Elten Schrama, Sımone A P van Luxemburg-Heıjs, JHF Falkenburg, Cornelıs J M Melıef, \\ and Els Goulmy
}

\begin{abstract}
After allogeneic bone marrow transplantation (BMT), the beneficial graft-versus-leukemia (GVL) effect but also the life-threatening graft-versus-host disease (GVHD) are mediated by $T$ cells of the grafted marrow The identification of leukemia cell-reactive $\mathbf{T}$ cells and their ligands are, therefore, crucial for the development of new anti leukemia strategies. Here we describe a leukemia-reactive allo-HLA class II restricted $\mathrm{CD4}^{+}$T-cell clone, 6.2 , Isolated from a healthy individual after stımulation with allogeneic leukemic cells. Clone 62 recognizes leukemic cells from several AML patients without showing reactivity to unfractıoned peripheral blood mononuclear cells, monocytes, $B$ cells, T-cell blasts, and proximal tubulus epithelial cells. Interestingly, clone 6.2
\end{abstract}

$\mathbf{A}$ LLOGENEIC bone marrow transplantation (BMT) is the therapy of choice for the treatment of several hematologic malignancies, such as leukemid ' Today the occurrence of graft-versus-host disease (GVHD) remains a major complication of the BMT ${ }^{25}$ In the current view, both GVHD and graft versus leukemid (GVL) effects of the BMT are mediated by donor derived mature $\mathrm{T}$ cells Depletion of $\mathrm{T}$ cells from the BM effectively prevents GVHD, but results in a high rate of leukemia relapses ${ }^{68}$ Furthei moie, patients with relapsed chronic myeloid leukemia can be effectively treated by administration of donor lymphocytes ${ }^{9}$ Several climical trials show a direct association between GVL and GVHD and suggest that the GVL effect may be the reflection of the antihost reactivity agdinst leukemic cells and is, there fore, not separable from GVHD ${ }^{41011}$ On the other hand, recent andyses of a large number of patients in the International Bone Marrow Tiansplantation Register point out that GVL can be observed independent of serious GVHD ${ }^{12}$ Also, results from experimental murme models suggest that GVL and GVHD can be mediated by separate as well as by ident1cdl T-cell populations ${ }^{1316}$ These data have been dlso supported by some recent studies in humans where T-cell lines and clones could be isolated, and these preferentially recognized leukemic cells ${ }^{1722}$ These in vitro studies, together with the clinical data, suggest that leukemid-associated antigens must exist Nevertheless, in most cases the isolated $T$ cells appeared not solely leukemıa specific or difficult to maintaın in vitro ${ }^{1821}$

In our serrch for $\mathrm{T}$ cells that are reactive with leukemiaassociated antigens, we have investigated the in vitro T-cell response of a healthy individual aganst the leukemic cells of an HLA class II mismatched unrelated AML patient with AML M1 classification We have isolated several T-cell clones, of which the majolity was directed agdinst subtle HLA class II differences between the responder and the stimulator One $\mathrm{CD}^{+}$proliferative and cytotoxic $\mathrm{T}$-cell clone recognized only leukemic cells from several AML patients in an allo-HLA-DR restricted fashion This T-cell clone also recognized HLA class II matched BM cells Nelther $\mathrm{CD}_{34^{-}}$, more differentiated precursors in the BM nor mononuclear cells in the peripheral blood (PB) are recognized by $T$ cell clone 62 , suggesting that its target antigen is also recognizes BM cells derived from healthy individuals and inhibits the colony formation of myeloid and erythroid cell lineages. In the BM, clone 6.2 recognizes only $\mathrm{CD} 34^{+}$ early precursor cells but not $\mathrm{CD}^{-}{ }^{-}$, more differentiated cells. Thus, the target antigen of clone 6.2 is developmentally regulated and expressed only by leukemic cells and $\mathrm{CD} 4^{+}$early progenitor cells in the hematopoietic system. We suggest that targeting the T-cell immune response to leukemı-associated, developmentally regulated antigens of the hematopoietic system can provide a basis for the separation of GVL from GVHD, and may lead to new therapeutic approaches for residual and relapsed leukemia.

(c) 1997 by The American Society of Hematology.

expressed only on leukemic cells and on early hematoporetıc progenitor cells

\section{MATERIALS AND METHODS}

Isolation of PB Mononuclear Cells (PBMCs), Leukemıc Cells, and BM Cells

PBMCs or BM cells from healthy donors and acute myelond leukemia (AML) patients were isolated by Ficoll-hypaque (Pharmacia, Uppsala, Sweden) density centrifugation Cell samples from AML patients that contained greater than $95 \%$ morphologically recognizable leukemic cells were further assigned as "leukemic cells" Leukemic cells, PBMCs, and BM cells were cryopreserved in $10 \%$ dimethyl sulfoxide and stored in liquid nitrogen until use

\section{Isolation of Monocytes, Untransformed B Cells, and BM Cell Fractions}

Patients' PBMCs or BM cells from healthy individuals were labeled with the indicated fluorescen-conjugated antibodies (Becton Dickinson) Monoclonal antibody (MoAb)-labeled cells were positively sorted using a fluorescein-activated cell sorter (FACS)

\section{Epstein-Barr Virus-Transformed B Lymphoblastotd Cell Lines $(E B V-B L C L)$}

PBMCs wele incubated with EBV during 15 hours at $37^{\circ} \mathrm{C}$ After washing, the cells were cultured in RPMI $+20 \%$ fetal calf serum (FCS) in the presence of 30 Gy irradiated feeder cells consisting of

From the Departments of Immunohematology and Blood Bank and Haematology, Leiden University Hospttal, Leiden The Netherlands

Submutted November 12, 1996 accepted March 141997

Supported by grants from the Dutch Cancer Foundation (Koningm Wilhelmina Fonds) and the J A Cohen Institute for Radiopathology and Radiation Protection (IRS)

Address reprint requests to Tuna Mutw, MD, PhD Department of Immunohematology and Blood Bank, Letden Unvversity Hospital Bldg1, E3-Q, Box 9600, 2300 RC Lelden The Netherlands

The publication costs of this article were defrayed in part by page charge payment This article must therefore be hereby marked "advertisement" in accordance with 18 US C section 1734 solely to indicate this fact

(C) 1997 by The Amencan Society of Hematology 0006-4971/97/9003-0025\$3 00/0 
PBMCs from six random donors The EBV-transformed $B$ cells were further expanded in RPMI $+10 \%$ FCS

\section{Phytohemagglutmin (PHA) Blasts}

PBMCs were cultured in the presence of $01 \mu \mathrm{g} / \mathrm{mL}$ PHA for 3 days Activated T-cell blasts (PHA blasts) were further expanded for three days using recombinant interleukn-2 (rIL-2) $(20 \mathrm{U} / \mathrm{mL})$ contanning culture medium

\section{Generation of Leukemia-Reactive T-Cell Lines and Clones}

Strmulator cells Leukemic cells of an AML patient with AML-M1 subclassification were used as stimulator cells The HLA typing of the leukemic cells was HLA-A3,-B7,-B62,-Cw7, DR13(DRB1*1302),-DR15(DRB 1*1501), -DR52(Dw26)(-DRB3*0301), -DQw6(DQB1*0602, *0604), -DPB1*0301,*0601

Responder cells PBMCs of a healthy individual were used as responder cells The HLA typing of the responder cells was HLAA3,-B7,-B62,-Cw7,-DR13(DRB1*1301),-DR15(DRB1*1501), DR52(Dw25)(-DRB3*0202)，-DQw6(DQB 1*0602,*0603/07), DPB $1 * 0401, * 0402$

Before the induction of primary T-cell cultures, stmmulator levkemic cells were cultured for 72 hours with a cocktall of cylokınes consisting of $800 \mathrm{U} / \mathrm{mL}$ granulocyte-macrophage colony-stumulating factor (GM-CSF, kndly provided by Dr Osanto, Le1den, The Netherlands), 1,000 U/mL IL-4 (Genzyme, Leuven, Belgium), and $150 \mathrm{U} /$ $\mathrm{mL}$ tumor necrosis factor- $\alpha$ (TNF- $\alpha$, Genzyme), in RPMI supplemented with $10 \%$ FCS, and antıbiotics (penicillı $100 \mathrm{U} / \mathrm{mL}$, streptomycin $100 \mu \mathrm{g} / \mathrm{mL}$ ) A total of $10^{7}$ cytokıne-treated, urradiated ( 30 Gy) leukemic cells were cocultured with $10^{7}$ responder cells in 5 $\mathrm{mL}$ of culture medium (RPMI supplemented with $15 \%$ human serum [HS] and antıbrotics), at $37^{\circ} \mathrm{C}$, and $5 \% \mathrm{CO}_{2}$ On day $620 \mathrm{U} / \mathrm{mL}$ of rIL-2 was added in the culture On day 8 the T-cell line was restımulated with urradiated leukemic cells On day 15 the T-cell line was cloned by limiting dilution at 03 cells/well in 96-well round-bottom microtiter plates in the presence of a feeder cell mixture containing irradiated PBMCs $(30 \mathrm{~Gy})$ from six random donors $\left(1 \times 10^{6}\right.$ cells $/$ $\mathrm{mL})$, irradiated leukemic cells $(30 \mathrm{~Gy})\left(25 \times 10^{5} \mathrm{c} / \mathrm{mL}\right), 20 \mathrm{U} / \mathrm{mL}$ rIL-2, and 1\% Leucoagglutınin-A (Sigma, St Lours, MO) rIL-2, 20 $\mathrm{U} / \mathrm{mL}$, was added to the cultures every 72 hours The T-cell clones were expanded by weekly restimulations with the above-described feeder cell-cytokine mixture and tested for leukemia-specific cytotoxic and proliferative activities

$T$-cell proliferation assays One to $2 \times 10^{4}$ responder $\mathrm{T}$ cells were cocultured with irradiated stimulator cells $\left(2\right.$ to $10 \times 10^{4} \mathrm{c} /$ well) in 96-well flat-bottom microtiter plates during 88 hours Sixteen hours before harvesting the cultures were labeled with $05 \mu \mathrm{C}$ of ${ }^{3} \mathrm{H}$-thymidıne The ${ }^{3} \mathrm{H}$-thymidine incorporation was determined by liquid scintillation counting The results are expressed as the mean of duplicate or triplicate cultures The SEM of the results never exceeded $15 \%$

Cytotoxicty assays ${ }^{51} \mathrm{Cr}$-labeled target cells $(3,000 /$ well) were incubated with serial dilutions of effector $T$ cells in 96 -well roundbottomed microtiter plates (Costar 3799, Cambridge, MA) After 4 hours of uncubation at $37^{\circ} \mathrm{C}$, cell-free supernatants were obtaned for gammd counting The percent specific lysis was calculated as follows \% Specific Lysis $=$ (Experimental Release - Spontaneous Release)/(Maximal Release - Spontaneous Release) $\times 100 \%$ Spontaneous release and the maximal release are the chromium release of target cells in culture medium alone and in culture medium contauning 1\% Triton-X 100 (Fluka, Buchs, Switzerland), respectıvcly

To use as target cells, proximal tubulus epithelium cells (PTEC) were trypsinated and seeded at 3,000 c/well in 96-well flat-bottom microtiter plates After allowing adherence, TNF- $\alpha(150 \mathrm{U} / \mathrm{mL})$ and interferon- $\gamma$ (IFN $-\gamma)(200 \mathrm{U} / \mathrm{mL})$ were added to the wells to induce the HLA class II expression PTEC were cultured in the presence of cytoknnes for 72 hours Twelve hours before the assay ${ }^{5 i} \mathrm{Cr}(3$ $\mu \mathrm{C} 1 /$ well) was added to the wells After washing, ${ }^{51} \mathrm{Cr}$ labeled, adherent PTEC were used as target cells m cytotoxicity assays

Hematopoietc precursor cell (HPC) growth inhibition assays HPC growth inhibition assays were performed as described previously ${ }^{23}$ Briefly, $125 \times 10^{5}$ bone marrow mononuclear cells (BMMNC) was mixed with effector $\mathrm{T}$ cells at different $\mathrm{T}$ BM cell ratios in $02 \mathrm{~mL}$ of HPC culture medium (Iscove's modified Dulbecco's medium [IMDM] supplemented with $30 \%$ plasma, $05 \%$ bovine serum albumin [BSA], $047 \mathrm{~g} / \mathrm{L}$ transferrnn, $5 \times 10^{5} \mathrm{~mol} / \mathrm{L}$ mercaptoethanol, and $10 \%$ culture supernatant of $\mathrm{T}$ cells) The cells were then ether immediately resuspended to a final volume of $14 \mathrm{~mL}$ with semisolid HPC medium supplemented with $10 \mathrm{ng} / \mathrm{mL}$ rGM-CSF, 50 $\mathrm{ng} / \mathrm{mL}$ rlL-3 (both from Sandoz, Basel, Switzerland), 2 IU r-erythropoietun (Cilag AG Int, Zug, Switzerland), and $13 \%$ methyl cellulose, or briefly centrifuged $(1,000 \mathrm{~g}, 15$ seconds) to establish $\mathrm{BM}$-T-cell contact and incubated for 4 hours at $37^{\circ} \mathrm{C}$ in $5 \% \mathrm{CO}_{2}$ before transferring to the semisolid medium One milliliter of the semisolid suspension was plated in $30-\mathrm{mm}$ plastic dishes and incubated at $37^{\circ} \mathrm{C}$ in $5 \%$ $\mathrm{CO}_{2}$ After 14 days the number of erythrocyte burst-forming units (BFU-E), colony-forming unit-granulocyles (CFU-G), and CFUmonocytes (CFU-M), defined as typical cell aggregates of more than 20 cells, were scored under an inverted microscope The percentage HPC growth inhibition is calculated as follows \% HPC Growth Inh1bition $=(1-$ No of Colonies in the Presence of Effector Cells/No of Colonies Without Effector Cells) $\times 100 \%$

\section{RESULTS}

\section{In Vitro Generatıon of Leukemia Reactive T-Cell Lines} and Clones

The PBMCs of a healthy individual were used to generate in vitro T-cell responses against leukemic cells of an unrelated AML pdtient The responder individud and the patient were serologically HLA identical, but showed subtle differences in HLA-DR, -DP, and -DQ genotypings (see Materıals and Methods). Before using ds stimulator cells, the leukemic cells were cultured with GM-CSF, IL-4, and TNF- $\alpha$ during 72 hours to increase their antigen-presenting capacity. The generated T-cell line showed proliferative and cytotoxic activity agdinst leukemic cells at day 8 (data not shown) Several $\mathrm{T}$-cell clones derived from this $\mathrm{T}$-cell line were tested dgainst leukemic cells, patient's EBV-BLCL, and HLAtyped PBMCs from healthy individuals. Based on the reaction patterns, four types of T-cell clones could be distingurshed (F1g 1) (1) The type I T-cell clones $(n=25)$ were reactive against both leukemic cells and EBV-BLCL Thus, these clones were not able to discriminate leukemic from nonleukemic cells (2) The type II T-cell clones $(\mathrm{n}=7)$ were reactive only to EBV-BLCL, suggesting that EBVassocidted antigens were recognized. (3) The type III T-cell clones $(n=19)$ were reactıve against leukemic cells but did not show redctivity against patient's EBV-BLCL, suggesting that their target antigen(s) were present on leukemuc cells but not on nonleukemic EBV-BLCL However, when these T-cell clones were tested agdinst a panel of PBMCs, which expressed the mismatched HLA class II antigens of the pdtient, all T-cell clones recognized one of more PBMCs Thus, type III T-cell clones were not directed against leukemiadssociated antigens, but most probably to alloantigens that were expressed by PBMCs but not by EBV-BLCL

\section{Specufic Recognttion of Pattent's Leukemic Cells by the CD4 $4^{+}$-Cell Clone 62}

One remaining $\mathrm{CD}_{4}{ }^{+} \mathrm{T}$-cell clone, designated as 62 , recognized leukemic cells but did not show reactıvity aganst 


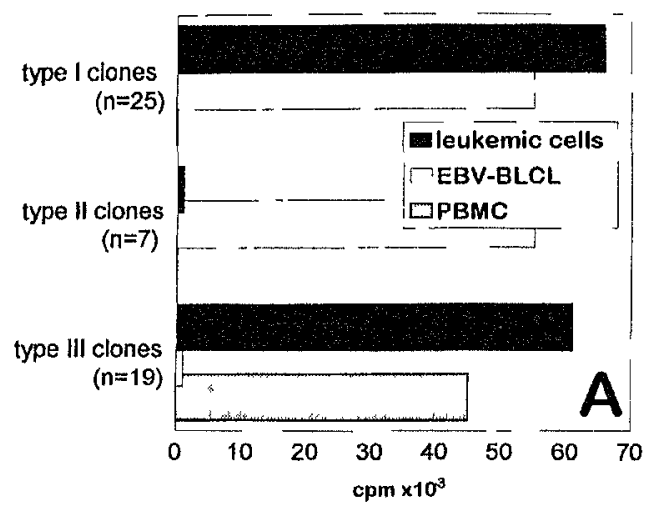

Stimulator celis

Patient's cells

leukemic cells

EBV-BLCL

monocytes

$B$ cells

Healthy individuals' PBMC

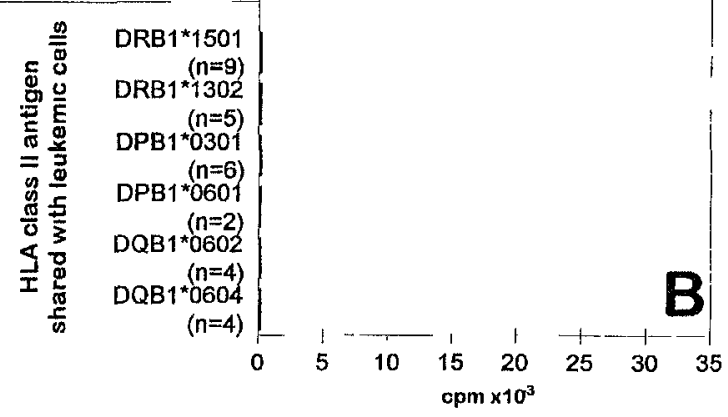

Fig 1. Specific recognition of original stimulator leukemic cells by the $\mathrm{CD4}^{+} \mathrm{T}$-cell clone 6.2 . (A) The proliferative activity of different types of T-cell clones against patient's leukemic cells (AML. cells), patient's EBV-BLCL, and HLA matched PBMCs. For each type of clone, the reactivity of one representative clone is shown. The number of clones displaying similar reactivity patterns is indicated in the brackets. (B) The proliferative activity of T-cell clone 62 against leukemic cells, patient's monocytes, patient's transformed or untransformed $B$ cells, and unrelated PBMC that share HLA class II antigens with the AML patient. CD 14 ${ }^{+}$monocytes and CD 19/20 ${ }^{+}$B cells were isolated from PBMC of the patient by FACS sorting. Similar results were obtained in at least three independent experiments.

EBV-BLCL, CD $19 / 20^{+}$untranstormed B cells, or CD $14^{+}$ monocytes that were derived from the PBMCs of the patient (Fig 1B) Furthermore, clone 62 did not show reactivity against a panel of PBMCs that shared HLA-cldss II antigens with leukemic cells (Fig 1B) These results indicated that $T$ cell clone 62 was not directed against antigens expressed by PBMCs, monocytes, or B cells but reacted to an antigen that is expressed only by leukemic cells.

\section{T-Cell Clone 62 Is Restricted Via the Allo HLA-DRw26 Molecule}

As shown in Fig 2A, the proliferative activity of the clone 62 agdınst leukemıc cells was completely blocked by MoAb
73.191 that is directed to HLA-DRB3 locus (HLA-DR52) ${ }^{24}$ Antibodies directed to HLA class I, HLA-DP, or HLA$\mathrm{DQ}^{2526}$ were not inhibitory The MoAb 7.3191 did not inhibit the recognition of the leukemic cells by a control HLADP-reactive T-cell clone (Fig 2A, right panel) illustrating 1ts specific inhibitory effect on clone 62 Because all cells that are positive for HLA-DRB1*1302 express the DR52 subtype HLA-Dw26 (DRB3*0301), the antigen recognition by clone 62 is restricted by HLA-Dw26. Note that the responder cells are also HLA-DR52-positive but are genotypically typed as HLA-DRB $3{ }^{*} 0202$ (see Materials and Methods) Thus, the T-cell clone 6.2 recognizes its leukemı-

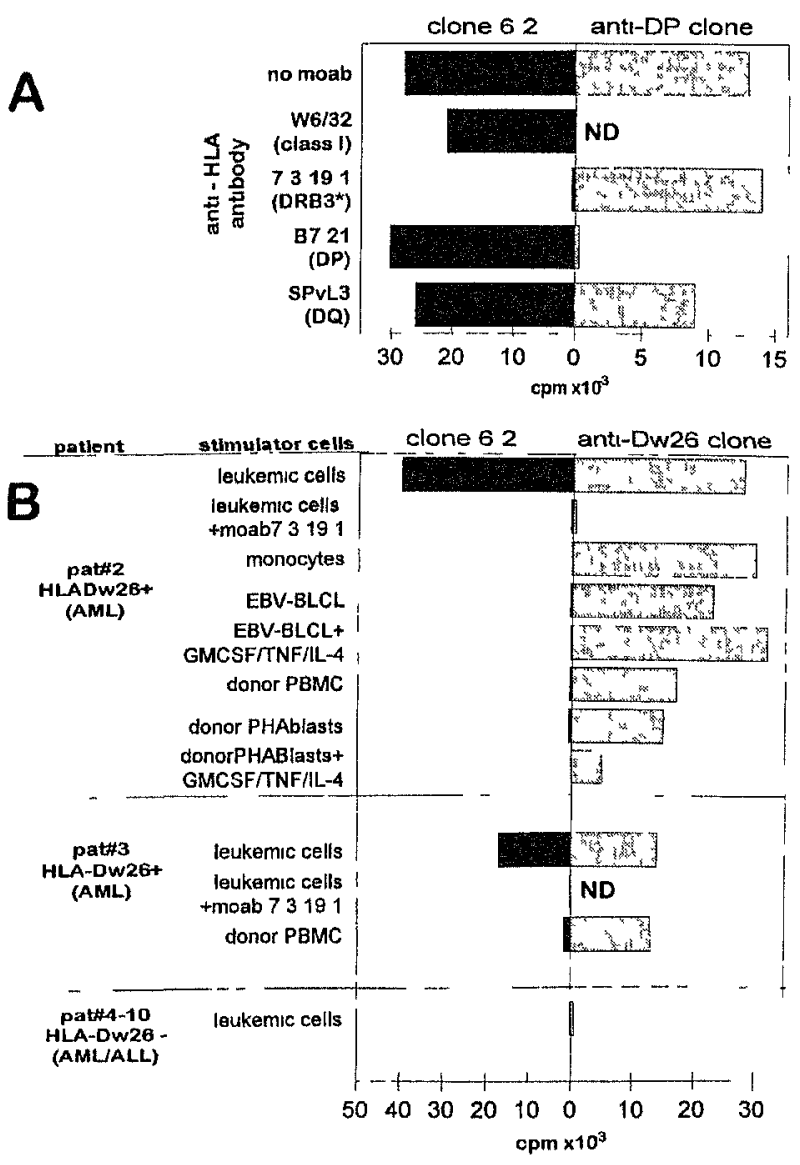

Fig 2. T-cell clone 6.2 is restricted by HLA-DRB3 locus product HLA-Dw26 and specifically recognizes HLA-Dw26-positive leukemic cells (A) Effect of HLA specific MoAbs on the recognition of leukemic cells by T-cell clone 62 (left panel) and a control DP reactive T-cell clone (right panel). The target specificities of the MoAbs are indicated in brackets. MoAbs were added in the proliferation assays at 1.100 dilution. ND, not tested. (B) Proliferative activity of T-cell clone 6.2 (left panel) and the HLA-Dw26 specific alloreactive T-cell clone (right panel) against different leukemic and nonleukemic cells Patients no. 2 and 3 are HLA-Dw26-positive AML-M1 patients; patients no.4 to 10 are HLA-Dw26-negative AML. or ALL patients (3 AML-M1, 1 AMLM3, 1 AML-IM5, 1 ALL patient). MoAb 17.319 .1 is added in the assay. $\mathrm{CD}_{14}{ }^{+}$monocytes from patient no 2 were obtained from PBMC by FACS sorting. EBV-BLCL and PHA blasts were also tested after culturing with GM-CSF $(800 \mathrm{U} / \mathrm{mL})+$ TNF- $\alpha(50 \mathrm{U} / \mathrm{mL})+\mathrm{IL}-4(500 \mathrm{U} / \mathrm{mL})$ for 72 hours. The thymidine uptake of T-cell clone 62 alone and the stimulator cells alone did not exceed $500 \mathrm{cpm}$. 
Effector cells:

clone 6.2

anti-DR Tcell line

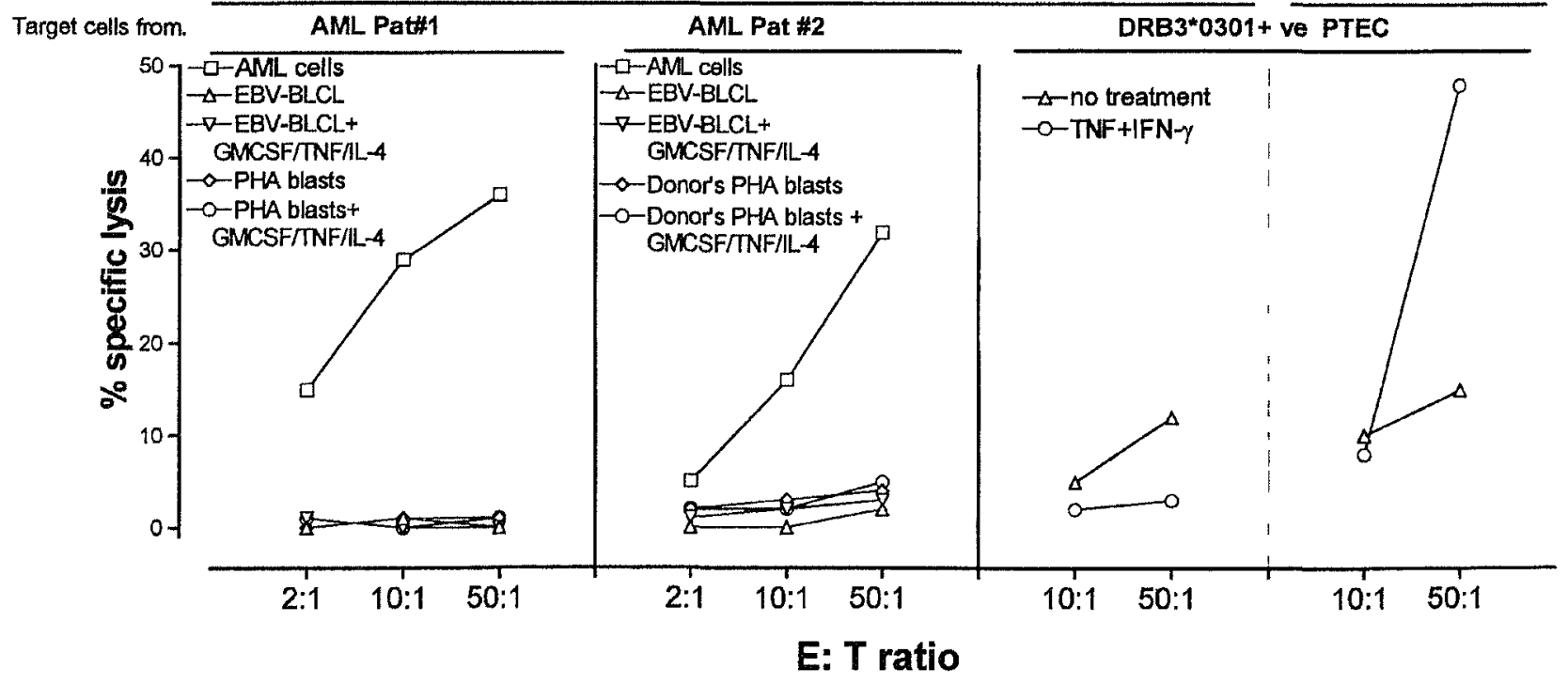

Fig 3. Specific cytotoxıc activity of T-cell clone 62 against leukemic cells Patients no. 1 and 2 are leukemia patients with AML-M1 designation. EBV-BLCL and PHA blasts were also tested after culturing with $\mathrm{GM}-\mathrm{CSF}(800 \mathrm{U} / \mathrm{mL})+\mathrm{TNF}-\alpha(50 \mathrm{U} / \mathrm{mL})+\mathrm{IL}-4(500 \mathrm{U} / \mathrm{mL})$ for 72 hours. Adherent PTEC were prepared as targets as indicated in Materials and Methods. Percent specific release of target cells was determined in 4-hour standard $\mathrm{Cr}$ release assays.

associated target antigen in the context of a mismatched, allo HLA-Dw26 (DRB3*0301) molecule

\section{T-Cell Clone 62 Prolfferates Against Other HLA-Dw26- Positive AML Cells Without Showing Reactivity to Nonleukemic Cells}

The T-cell clone 62 was subsequently tested aganst a panel of leukemic and nonleukemic cells derived from different leukemid patients (Fig 2B, left panel) A CD4 ${ }^{+}$alloreactive T-cell clone specific for the HLA-Dw26 molecule was used as control (Fig 2B, right panel) Beside its reactivity dganst the original stimulator leukemic cells of the AMLM1 patient (no. 1) (Figs $1 \mathrm{~B}$ and 2A), clone 62 recognized two other leukemic cells from AML patients (nos 2 and 3) (Fig 2B, left panel) These leukemic cells were also recognized by the control HLA-Dw26 reactive T-cell clone (Fig $2 \mathrm{~B}$, right panel), confirming the expression of HLA-Dw26 on the cell surface Note that the proliferdtive activity of both clone 62 and HLA-Dw26 specific alloredctive T-cell clone against the leukemic cells of patient no 2 were blocked by antibody 73191 , illustrating the HLA-Dw26 dependency of the recognition Leukemic cells from six HLADw26-negative AML or acute lymphoblastond leukemia (ALL) patients were not recognized either by clone 62 or by the control HLA-Dw26-specific T-cell clone (Fig 2B)

The leukemic cell-specific reactivity of clone 62 is further demonstrated by absence of proliferation against different nonleukemic cell types obtained from patients no 2 and 3 Figure $2 \mathrm{~B}$ shows that clone 62 did not recognize the EBV-BLCL and monocytes derived from patient no 2, clone 62 also falled to recognize PHA blasts or PBMCs derived from the HLA-1dentical BM donors of patients no 2 and 3 The EBV-BLCL and PHA blasts that were treated with GM-
CSF/TNF- $\alpha /$ LL- 4 cocktall were also not stumulatory, indicating that the target antigen of clone 62 was not induced on BLCL or T cells by these cytokines All tested HLA-Dw26positive nonleukemic cells, including those that were treated with cytokines, were recognized by the control Dw26-reactive $\mathrm{T}$-cell clone (F1g 2B, right panel), showing that all assayed nonleukemic cells expressed the restriction molecule and were capable of stımulatıng $\mathrm{T}$ cells ( $\mathrm{F}_{1} \mathrm{~g} 2 \mathrm{~B}$, right panel)

\section{T-Cell Clone 62 Is Cytotoxic to Leukemic But Not to Nonleukemic Cells}

T-cell clone 62 not only possessed prolıferatıve actıvity against leukemic cells but also efficiently lysed the leukemic cells (Fig 3) Similar to its proliferative activity, the cytotoxic actıvity of clone 6.2 was confined to leukemic cells Nonleukemic cells such as PHA blasts or EBV-BLCL denved from the patients no 1 and 2 or from their HLA-1dentical BM donors were not lysed (Fig 3). BLCL or PHA blasts that were treated with the GM-CSF/TNF/IL-4 cocktall were also not lysed (F1g 3)

To assess whether nonhematoporetic cells can express the target antigen of clone 62 , an HLA-DRB3*0301-positive PTEC line was tested as target cell (F1g 3) Clone 6.2 and a control alloreactive $T$-cell line that is directed to HLADRB $1 * 1302$ and HLA-DRB3*0301 allo-determınants were used as effector cells Because PTECs do not constitutively express HLA class II, they were cultured with $200 \mathrm{U} / \mathrm{mL}$ IFN- $\gamma+150 \mathrm{U} / \mathrm{mL}$ TNF- $\alpha$ during 72 hours to induce HLA class II expression The control alloreactive $\mathrm{T}$-cell line showed a nonsignificant lysis against untreated PTEC which lacked HLA-class II The induction of HLA class II expression by IFN $-\gamma$ and TNF- $\alpha$ led to the recognition of the PTEC 


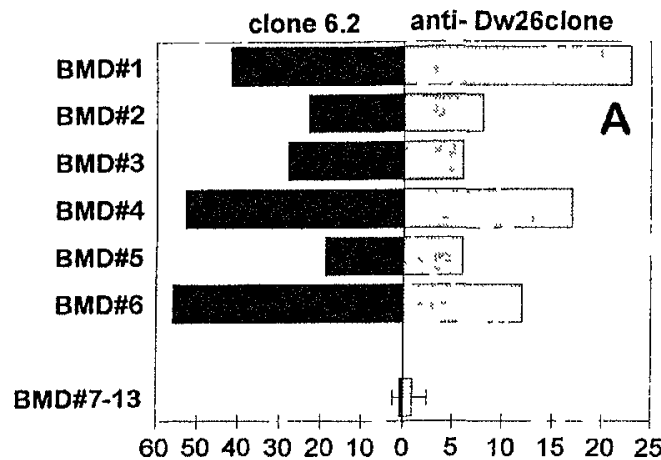

$60 \quad 50 \quad 40 \quad 3020 \quad 10 \quad 0 \quad 5 \quad 10 \quad 15 \quad 20 \quad 25$
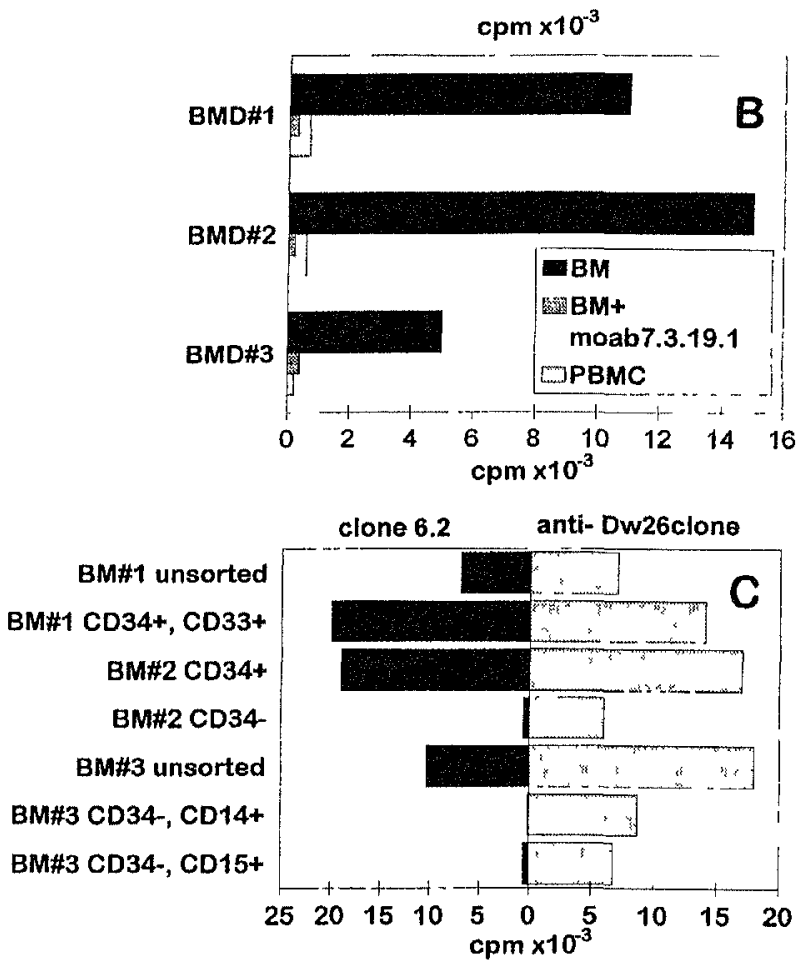

Fig 4. Specific recognition of HLA-Dw26-positive BM early progenitor cells by T-cell clone 6.2. (A) HLA-Dw26-positive or -negative BM cells from healthy individuals were used to stimulate clone 6.2 (left panel) and the control HLA.Dw26-specific alloreactive T-cell clone (right panel) in 88-hour standard proliferation experiments. (B) MoAb 7.3.19.1 is added in the assay. (C) Different subsets of BM cells were obtained by FACS sorting after labeling with appropriate antibodies, irradiated, and used in proliferation experiments as stimulator cells at $5 \times 10^{4}$ cells/well.

by the control alloreactive T-cell line only, suggesting that the PTEC did not expressed the target antigen of clone 6.2.

\section{T-Cell Clone 62 Recognizes CD34 ${ }^{+}$Hematopoietic Progenttor Cells and Inhibits the Growth of Erythroid, Monocytic, and Granulocytic Cell Lineages}

T-cell clone 6.2 was tested against a panel of BM cells derived from healthy individuals (Fig 4A, left panel). Likewise, the control HLA-Dw26-specific alloreactive T-cell clone, clone 6.2, recognized all HLA-Dw26-positive BM cells but did not recognize HLA-Dw26-negative BM cells
(Fig 4A). The proliferation of clone 6.2 against BM cells was inhibited by the antibody 7.3.19.1, confirming its HLADR-restricted reactivity (Fig 4B). As expected, the PBMC derived from the HLA-Dw26-positive BM donors were not recognized (Fig 4B). These results suggested that the clone 6.2 might recognize a developmentally regulated antigen that is expressed only by early progenitor cells present in the BM. To address this assumption, several FACS sorted BM cell populations were tested for their capacity to stimulate T-cell clone 6.2 (Fig 4C). T-cell clone 6.2 recognized the unsorted BM cells, CD34+ early progenitor cells, CD $34^{+}$, $\mathrm{CD}_{3}{ }^{+}$early myeloid cell precursors, but not $\mathrm{CD} 34^{-}$cells, including $\mathrm{CD}_{34}^{-}, \mathrm{CD}_{14}{ }^{+}$monocytic lineage and $\mathrm{CD}^{-} 4^{-}$, $\mathrm{CD} 15^{+}$granulocytic cell lineage. These results indicated that the target antigen recognized by the antileukemic $\mathrm{T}$-cell clone 6.2 was expressed by $\mathrm{CD} 34^{+} \mathrm{BM}$ early progenitor cells but not by more differentiated cells, including PBMCs. Note that the control HLA-Dw26-specific alloreactive Tcell clone recognized all cell subsets, indicating that the unresponsiveness of clone 6.2 to $\mathrm{CD} 34^{-}$cells was not caused by a lack of stimulatory capacity (Fig $4 \mathrm{C}$, right panel).

Because $\mathrm{T}$-cell clone 6.2 displays cytotoxic activity, we addressed the question of whether it could also lyse BM cells and inhibit the outgrowth of different hematopoietic cell lineages. Therefore, we used BM cells as target cells in cytotoxicity assays (Fig 5) and in parallel we performed HPC growth inhibition assays (Fig 6). A CD8 ${ }^{+}$HLA-A2specific CTL clone was used as control.

T-cell clone 6.2 showed specific cytolysis against two HLA-Dw26-positive, unfractionated BM cells. As expected, HLA-Dw26-negative BM cells were not lysed (Fig 5 , left panel). The moderate levels of lysis observed against these unfractionated BM cells was not surprising because clone 6.2 was expected to recognize only $\mathrm{CD} 34^{+}$cells in the BM. The control HLA-A2-specific $\mathrm{CD} 8^{+}$alloreactive T-cell clone significantly lysed the BM cells that were HLAA2-positive (Fig 5, right panel).

In HPC growth inhibition assays (Fig 6), clone 6.2 strongly inhibited the outgrowth of BFU-E, CFU-G, and CFU-M from two HLA-Dw26-positive BM (BM no. 1 and $\mathrm{BM}$ no. 2) at $\mathrm{T}: \mathrm{BM}$ ratios as low as 0.3:1. HLA-Dw26negative BM (BM no. 10, BM no. 11) were not inhibited, showing that the HPC inhibition was specific and dependent on antigen presentation by $\mathrm{BM}$ cells. Likewise, the control HLA-A2-specific CTL inhibited the HPC growth from only HLA-A2-positive BMs no. 1, 10, and 11. Both clone 6.2 and alloreactive T-cell clone inhibited the number of the growing colonies, and no difference in the size of the colonies was observed, suggesting that the further outgrowth of the colonies was not inhibited. Furthermore, neither clone 6.2 nor the $\mathrm{CD} 8^{+}$alloreactive clone inhibited the HPC growth when the T cells and the BM cells were only mixed immediately before plating in the semisolid culture medium (data not shown), indicating that the inhibition of HPC growth was dependent to cell-cell contact. These results were similar to those obtained by other $\mathrm{CD} 8^{+}$CTL directed to alloantigens or to minor histocompatibility antigens. ${ }^{23}$

Taken together, the strong HPC growth inhibition by clone 6.2 may reflect its cytotoxic activity against $\mathrm{CD} 34^{+}$early 


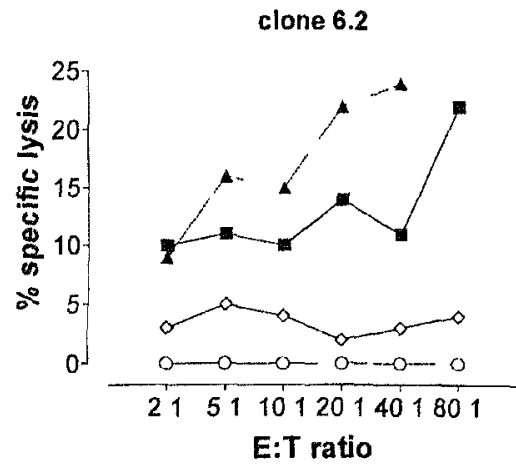

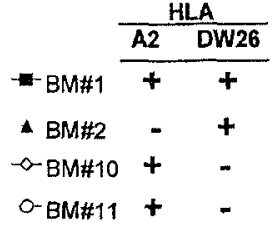

Fig 5. Cytotoxic activity of clone 6.2 to BM cells. Unfractionated BM cells were tested as target cells for clone 62 (left) and for an HLA-A2-specific, CD8 ${ }^{+}$alloreactive CTL (right) in 4-hour standard CML assays. precursor cells However, other mechanısms such as induction of apoptosis via fas-fasL interactions cannot be excluded

\section{DISCUSSION}

After an allogeneic BMT mature $\mathrm{T}$ cells present in the graft inoculum appear to play a major role in the elimination of residual leukemic cells ${ }^{69}$ The understanding of the nature of the T-cell response directed to leukemic cells and the identification of leukemia-associated T-cell antigens is the basis of new therapeutic methods against leukemia This 1ssue was the main focus of the present study

Over the past few years it became clear that the proper activation of naive $T$-cell precursors in primary in vitro cultures requires efficient antigen presentation supported by strong costimulatory signals delivered by the antigen presenting cell (APC) ${ }^{27}$ In this respect, leukemic cells may not function as proper APC since they usually lack or weakly express costimulatory molecules such as B7 1 and B7 2 This may be the reason why in some studies antileukemic T-cell lines and clones were reported to be functionally or physically unstable in culture Therefore, we decided to culture leukemic cells with GM-CSF, IL-4, and TNF- $\alpha$ These cytokınes, which are known to generate adequate APC from monocytes, ${ }^{28}{ }^{30}$ also increased the antigen-presenting capac1ty of acute myelord leukemia cells (manuscript in prepardtion)
Using this strategy, we investigated primary T-cell responses induced against allogeneic leukemic cells Beside $\mathrm{T}$-cell clones that were reactive to leukemic cells and patient's EBV-BLCL, we have isolated other alloreactive Tcell clones that recognized leukemic cells, HLA-matched, allogeneic PBMCs, but not patient's EBV-BLCL (Fig 1A, type III clones) These latter T-cell clones are probably d1rected to allo-HLA determinants, which are apparently absent on EBV-BLCL

More interestingly, we have isolated a T-cell clone, designated as "62," recognizing an antigen present on various leukemic cells but absent on nonleukemic cells isolated from the PB, and on the k1dney-derived PTEC This $\mathrm{CD}^{+}{ }^{+} \mathrm{T}$-cell clone appeared to recognize its target antigen not in a selfrestricted but in an allo HLA-DR - restricted fashion In this respect our results are in agreement with previous studies of Sosman et al, ${ }^{17}{ }^{18}$ who also have shown that allogeneic $T$ cells can display specific antrleukemic activity in vitro Similar to the $T$ cells described by Sosman et $a l$, the antileukemic Tcell clone 62 described here is $\mathrm{CD}^{+}$, class II restricted, and not only proliferates but also displays cytotoxic activity aganst leukemic cells Thus, it is plausible that GVL effect after BMT can be medidted also by antileukemic $\mathrm{CD}^{+} \mathrm{T}$ cells Some recent studies indeed suggest that $\mathrm{CD} 4^{+} \mathrm{T}$ cells can mediate GVL effects without the apparent induction of GVHD ${ }^{31}$ Moreover, in a recent clinical trial, the GVL effect of the buffy coat transfusion was preserved by the depletion
Fig 6 HPC growth inhibition by T-cell clone 62 . T-cell clone 62 is preincubated with BM cells at indicated T-cell.BM cell ratios for 4 hours at $37^{\circ} \mathrm{C}$ The cells were then transferred into semisolid HPC growth medium and cultured in cell culture dishes to allow HPC growth. The colony formation in semisolid medium is determined by light-microscopy after 10 days. Percent inhibition of the HPC growth was de. termined as follows \% Inhibition $=11-$ No. of Colonies in the Presence of T-Cell Clone/No of Colonies in the Absence of T-Cell Clone ) $\times 100 \%$.

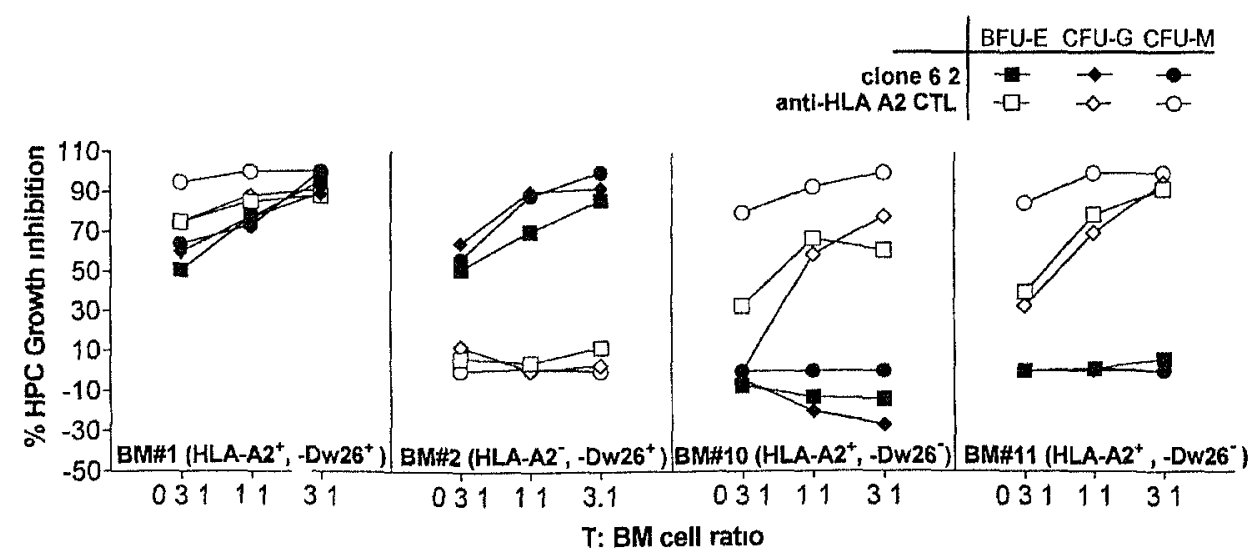


of $\mathrm{CD}^{+}$cells, whereds the GVHD was largely prevented after this procedure ${ }^{32}$

So far little is known about the nature of the leukemiaassociated antigens that trigger $\mathrm{T}$-cell immune responses Several investıgators consider leukemid-specific fusion proteins, such ds the characteristic BCR-ABL fusion protein in chronic myeloid leukemia (CML), as potentidl candidates for targeting the T-cell 1 mmune response specifically to leukemic cells ${ }^{33}$ Although $\mathrm{T}$ cell responses can be generdted agdinst the BCR-ABL fusion peptides, it has not been con vincingly shown that BCR-ABL fusion product is naturally expressed in the context of HLA molecules In acute leukemids a variety of tumol-specific chromosome abnormalities occur Although the fusion products of these chromosomal translocations can be also considered as target antigens for the development of leukemid specific therapies, not a laige percentage of patients can be cured by such strategies because of the interindividual variation in the chromosomal abnormalities However, several of these divers chromosomal translocations led to the activation of common transcription factors that are important in differentiation ${ }^{34} \mathrm{As}$ yet it is not known whether these developmentally regulated antigens could trigger $T$-cell immune responses and seive as leukemia-associated T-cell antigens Our current results suggest that possibly such developmentally regulated antigens can be recognized by $T$ cells The HLA-DR restricted T-cell clone 62 described here specifically recognizes leukemic cells from severd AML patients and reacts to CD34 $\mathrm{BM}$ cells without showing reactivity against CD34 BM cells or agdınst nonleukemic cells derived from PBMC The target antigen of clone 62 is also not present on a nonhematoporetıc system-derived cell line PTEC Although we were not able to test other somatic tissue cells, and thus it still remains possible that an other cell type can be recognized, so far clone 62 shows a very limited target cell specificity in the hematopoietic system The most likely explandtion of this specific target cell specificity is that clone 62 recognizes a developmentally regulated antigen of the hematoporetic system, which is involved in the differentiation of early pro genitor cells This antigen is also expressed on leukemic cells that are arrested in an early stage of the differentiation Because the $\mathrm{T}$ cell clone effectively inhibits the outgrowth of hematopoietic precursor cells and lyses the leukemic cells, the use of this clone for the treatment of leukemid after BMT may result in elimination of residual leukemic cells in the $\mathrm{PB}$ and their precursors in the BM without the risk of GVHD The man criticism agdinst such a therapeutic approach is that the T-cell clone o 2 will also tecognize grafted BM and presumably will not allow the outgrowth of several cell lineages This risk can be avorded by transplantation of an HLA-Dw26-negative, thus a one allele HLA DR mismatched BM graft, because the T-cell clone 62 will recognize its target antigen only in the context of HLA-Dw26 It is obvious that in such a transplantation setting the BM graft should be T-cell depleted to dvold the risks of serious GVHD and the rejection of the CTL clone Alternatively, furnishing the T-cell clone 62 with a surcide gene, such as Hs.v-tk gene, may allow the control of the T-cell clone in vivo betore BMT
In conclusion, our results suggest that targeting the $\mathrm{T}$ cell immune response to the developmentally regulated antigens of the hematopoietic system may be possible, and lead to new approaches in the leukemia treatment

\section{ACKNOWLEDGMENT}

We thank Drs F Koning and T Ottenhoff for critical discussions

\section{REFERENCES}

1 Sullivan KM Congress Review Progress and prospects in bone marrow transplantation Transplant Proc 21 2919, 1989

2 Weiden PL, Flournoy N, Thomas ED, Prentice R, Fefer A, Buckner CD, Storb R Antlleukemic effect of graft versus host disease in human recipients of allogeneic marrow grafts $\mathrm{N}$ Engl J Med 3001068,1979

3 Weiden PL, Sullivan KM, Flournoy N, Storb R, Thomas ED Antıleukemic effect of chromic graft-versus-host-disease $\mathrm{N}$ Engl J Med 304 1529, 1981

4 Sullivan KM, Weiden PL, Storb R, Witherspoon RP, Fefer A, Fisher L, Buckner CD, Anasett C, Appelbaum FR, Bagder C, Beatty P, Besinger W, Berenson R, Bigelow C, Cheever MA, Clift R, Deeg HJ, Doney K, Greenberg P, Hansen JA, Hıll R, Laughran T, Martın $P$, Neiman P, Peterson FB, Sanders J, Singer J, Stewart P, Thomas ED Influence of acute and chronic graft versus host disease on relapse and survival after bone marrow transplantation from HLAidentical siblings as treatment of acute and chronic leukemia Blood 731720,1989

5 Ferrara J, Deeg HJ Graft-versus-host disease N Engl J Med 324667,1991

6 Poynton $\mathrm{CH}$ T cell depletion in bone marrow transplantation Bone Marrow Transplant 3265,1988

7 Marmont AM, Horowitz MM, Gale RP, Sobocinsk K, Ash RC, van Bekkum DW, Champlin RE, Dicke KA, Goldman JM, Good RA, Herzig RH, Hong R, Masaoka T, Rimm AA Ringden $\mathrm{O}$, Speck B, Weiner RS, Bortin MM T cell depletion of HLA identical transplants in leukemia Blood 78 2120, 1991

8 Gale RP, Champlin RE How does bone-marrow transplantation cure leukemia Lancet 2 28, 1984

9 Kolb HJ, Mittermuller J, Clemm CH, Holler E, Ledderose G, Brehm G Heim M, Wilmanns W Donor leukocyte transfusions for treatment of recurrent chronic myelogenous leukemia in marrow traansplant patients Blood 76 2462, 1990

10 Weıden PL, Fluornoy N, Sanders JE, Sullivan KM, Thomas ED Anti-leukemic effect of graft-versus-host disease contributes to improved survival after allogeneic bone marrow transplantation Transplant Proc 13 248, 1981

11 Slavin S, Ackerstern A, Naparstek E, Or R, Weiss L The graft-versus-leukemia (GVL) phenomenon Is GVL separable from GVHD? Bone Marrow Transplant 6 155, 1990

12 Horowitz MM, Gale RP, Sondel PM, Goldman JM, Kersey J, Kolb HJ, Rimm AA, Ringden O, Rozman C, Speck B Graft versus leukemia reactions after bone marrow transplantation Blood 75555,1990

13 Tutschka PJ, Berkowitz SD, Tuttle S, Klenn J Graft-versusleukemia in the rat-The antleukemic efficacy of syngenerc and allogeneic graft-versus-host disease Transplant Proc 141 2668, 1987

14 Bortın MM, Rımm AA, Saltzsteın EC, Rodey E Apparent independent ant1-host and ant1-leukemic activity of transplanted 1mmunocompetent cells Transplantation 16 182, 1973

15 Bortm MM, Tiuitt RL, Rimm AA, Bach FH Graft versus leukemra reactivity induced by allommunization without augmentation of graft versus host reactivity Nature 281490,1979

16 Truitt RL, Shih CY, Lelevre AV, Tempehs LD, Andreanı M, Bortin MM Characterısation of alloımmunısation-1nduced $T$ lym- 
phocytes reactive agdınst AKR leukemia in vitro and correlation with graft-versus-leukemia activity in vivo J Immunol 1312050 , 1983

17 Sosman JA, Oettel KR, Hank JA, Fisch P, Sondel PM Specific recognition of human leukemic cells by allogeneic $T$ cell lines Transplantation 48 486, 1989

18 Sosman JA, Oettel KR, Smith SD, Hank JA, Fisch P, Sondel PM Specific recognition of human leukemic cells by allogenerc cells II Evidence for HLA-D restructed determinants on leukemic cells that are crossreactive with determinants present on unrelated nonleukemic cells Blood 75 2005, 1990

19 van Lochem E, de Gast GC, Goulmy E In vitro separation of host specific graft-versus-host and graft-versus-leukemia cytotoxıc $\mathrm{T}$ cell activities Bone Marrow Transplant 10 181, 1990

20 Falkenburg JHF, Faber LM, van den Elshout $M$, van Luxemburg-Heijs SAP, Hooftman-den Otter A, Smit WM, Voogt PJ, Willemze R Generation of donor-derived ant1leukemic cytotoxic $T$-lymphocyte responses for treatment of relapsed leukemı after allogenerc HLA-ıdentical bone marrow transplantation J Immunotherapy 14305,1993

21 Faber LM, van Luxemburg-Heys SAP, Willemze R, Falkenburg JHF Generation of leukemia-reactive cytotoxic $\mathrm{T}$ lymphiocyte clones from the HLA-idenucal bone marrow donor of a patient with leukemid J Exp Med 1761283,1992

22 Hoffmann T, Theobald M, Weiss BM, Hermpel H, Helt W Frequency of bone marrow $\mathrm{T}$ cells responding to HLA-identical nonleukemic and leukemic stımulator cells Bone Marrow Transplant 121,1993

23 Marjt WAF, Veenhof WFY, Goulmy E, Willemze R, van Rood JJ, Falkenburg JHF Minor histocompatibility antigens HA$1,-2$, and -4 , and $\mathrm{HY}$ specific cytotoxic $\mathrm{T}$ cell clones inhrbit human hematoporetic progentor cell growth by a mechanism that is dependent on direct cell-cell contact Blood 82 3778, 1993

24 Koning F, Schreuder GMTh, Giphart MJ, Bruning JW A mouse monoclonal antibody detecting a DR-related MT2-like spec1ficity Serology and bıochemistry Hum Immunol 9221,1984

25 Spits H, Borst J, Giphat MJ, Coligan J, Terhorst C, de Vries
JE HLA-DC antigens can serve as recognition elements for human cytotoxic T lymphocytes Eur J Immunol 14299,1984

26 Rebai N, Malissen B, Dieres M, Acolla RS, Corte G, Mawas C Distinct HLA-DR epitopes and distinct families of HLA-DR molecules defined by 15 monoclonal antibodies $(\mathrm{mAb})$ esther antiDR or allo-ant1-Ia ${ }^{k}$ cross reacting with human DR molecule I Cross inhibition studies of mAb cell surface fixation and differential binding of mAb to detergent solubilized HLA molecules immobilized to a solid phase by a first mAb Eur J Immunol 13 106, 1983

27 Croft $M$ Activation of nave, memory and effector $T$ cells Curr Opin Immunol 6431,1994

28 de Waal Malefiyt R, Figdor CG, de Vries JE Effects of IL4 on monocyte functions Comparison to IL-13 Res Immunol 144629,1993

29 Sallusto F, Lanzavecchia A Efficient presentation of soluble antigen y cultured human dendritic cells is mantaned by granulocyte/macrophage colony-stimulating factor plus interleukin 4 and downregulated by tumor necrosis factor alpha J Exp Med 1791109 , 1994

30 Romanı N, Gruner S, Brang D, Kampgen E, Lenz A, Trockenbacher B, Konwalınka G, Fritsch PO, Steinman RM, Schuler G Prolıferating dendritic cell progenitors in human blood J Exp Med 18083,1994

31 Antm JH Gralt versus leukemia No longer an epiphenomenon Blood 82 2273, 1993

32 Gralt S, Hester J, Huh Y, Hirsch-Ginsberg C, Rondon G, Seong D, Lee M, Gajewskı J, van Besıen K, Khourı I, Mehra R, Przepıorka D, Korbling M, Talpaz M, Kantarjan H, Fischer H, Deisseroth A, Champlin R CD8-depleted donor lymphocyte infusion as treatment for relapsed chronic myelogenous leukemia after allogenetc bone marrow transplantation Blood 86 4337, 1995

33 Chen W, Peace BJ, Rovira DK, You SG, Cheever MA T cell 1mmunity to the joining region of p210 BCR-ABL protein Proc Natl Acad Sc1 USA 89 1468, 1992

34 Rabbitts TH Translocations, master genes and differences between the origins of acute and chronic leukemras Cell 67641 , 1991 